\title{
면역글로불린G4관련안질환을 동반한 중증 위아래눈꺼풀판겉말림 Severe Upper and Lower Tarsal Ectropion with Immunoglobulin G4-related Ophthalmic Disease
}

\author{
오준호·손병재 \\ Jun Ho Oh, MD, Byeong Jae Son, MD \\ 경북대학교 의과대학 안과학교실 \\ Department of Ophthalmology, School of Medicine, Kyungpook National University, Daegu, Korea
}

\begin{abstract}
Purpose: To present the first case of severe upper and lower tarsal ectropion associated with immunoglobulin G4 (IgG4)-related ophthalmic disease.

Case summary: A 37-year-old male presented with relapsed eyelid swelling and periocular inflammation in the left eye for 7 years. He had severe upper and lower tarsal ectropion and a thickened upper eyelid with prolapsed conjunctival fornix. Orbital computed tomography showed a poorly defined anterior orbital mass involving the lacrimal gland and upper and lower eyelids on the left eye. The severe upper and lower eyelid ectropion was corrected by a modified spindle procedure and lateral tarsal strip. Hard, ill-defined fibrotic tissue and a mass around the lateral upper tarsal plate were discovered that required excision of the mass and a biopsy. Hematologic and histopathologic findings of the orbital mass indicated lgG4-related ophthalmic disease with severe upper and lower ectropion caused by the disease.

Conclusions: In cases of severe upper and lower eyelid ectropion caused by chronic inflammation, as seen in this case, not only eyelid tightening with excision of the causative mass but also a modified spindle procedure is required to prevent rotation of the eyelid.
\end{abstract}

J Korean Ophthalmol Soc 2020;61(8):944-949

Keywords: Immunoglobulin G4-related ophthalmic disease, Modified spindle procedure, Upper and lower eyelid ectropion

눈꺼풀겉말림은 일반적으로 퇴행눈꺼풀겉말림 형태로 나타나는 것이 가장 흔하며, 눈꺼풀의 자연 노화로 인해 눈 꺼풀의 탄력이 약해지고, 수평이완이 발생하여 눈꺼풀테가 바깥으로 뒤집어지게 된다. ${ }^{1}$ 눈꺼풀겉말림의 다른 원인으 로 얼굴신경마비로 인한 마비눈꺼풀겉말림, 눈꺼풀 피부나

- Received: 2020. 3. 9.

- Revised: 2020. 4. 16.

- Accepted: 2020. 7. 29.

- Address reprint requests to Byeong Jae Son, MD Department of Ophthalmology, Kyungpook National University Hospital, \#130 Dongdeok-ro, Jung-gu, Daegu 41944, Korea Tel: 82-53-200-5806, Fax: 82-53-426-6552

E-mail: supersbj@hanmail.net

* Conflicts of Interest: The authors have no conflicts to disclose.
주변부 조직의 파괴로 인해 흥터가 발생하여 눈꺼풀이 겉 말리는 반흔눈꺼풀겉말림, 선천눈꺼풀겉말림 등이 있다. 눈 꺼풀겉말림은 주로 아래 눈꺼풀에 발생하여 위눈꺼풀에 발 생하는 경우는 극히 드물며, 성인에서는 눈꺼풀 앞층판의 단축을 발생시킬 수 있는 화상, 외상, 수술, 만성적인 태양 광 노출, 방사선 치료, 만성 피부염, 피부감염 등의 반흔성 원인에 의해 주로 발생하지만, ${ }^{2}$ 국외에서는 대개 위눈꺼풀 이완으로 인한 헐거운눈꺼풀증후군(Floppy eyelid syndrome) 과 관련이 깊다고 알려져 있다. ${ }^{3}$

면역글로불린G4관련질환(immunoglobulin G4 [IgG4]related disease)은 림프구와 $\mathrm{IgG} 4$ 분비 형질세포의 조직침 윤과 더불어 다양한 정도의 섬유화를 보이는 만성염증질환 으로서 전신 장기에 다발성으로 발생할 수 있다. 그중 다른 
장기의 침범 없이 안와에만 국한된 경우를 면역글로불린 $\mathrm{G} 4$ 관련안질환(IgG4-related ophthalmic disease)이라고 하는데 이는 전체 안와 주변 염증질환 중 약 5-20\%를 차지 한다고 하며, 유병률은 10,000 명 중 1 명으로 보고되어 있 다. ${ }^{4}$ 2012년 Research Program for Intractable disease of the Ministry of Health, Labor, and Welfare (MLHW)에서 면역 글로불린G4관련질환에 대한 정의와 진단 기준을 처음으로 제시하였으며, ${ }^{4}$ 이후 2014년에는 Goto et $\mathrm{al}^{5}$ 이 면역글로불 린G4관련안질환(IgG4-related ophthalmic disease)에 대해 영상의학검사, 병리조직학검사 및 전신혈액검사를 바탕으 로 하는 진단 기준을 제시하였다. 비반흔성 위눈꺼풀겉말 림은 극히 드문 질환이며, 현재까지 국내외에서 면역글로 불린G4관련안질환에 의한 위아래눈꺼풀겉말림은 보고된 적이 없는 상황으로 저자들은 이러한 사례를 경험하고 수 술적 교정을 성공적으로 시행하였기에 이를 보고하고자 한 다.
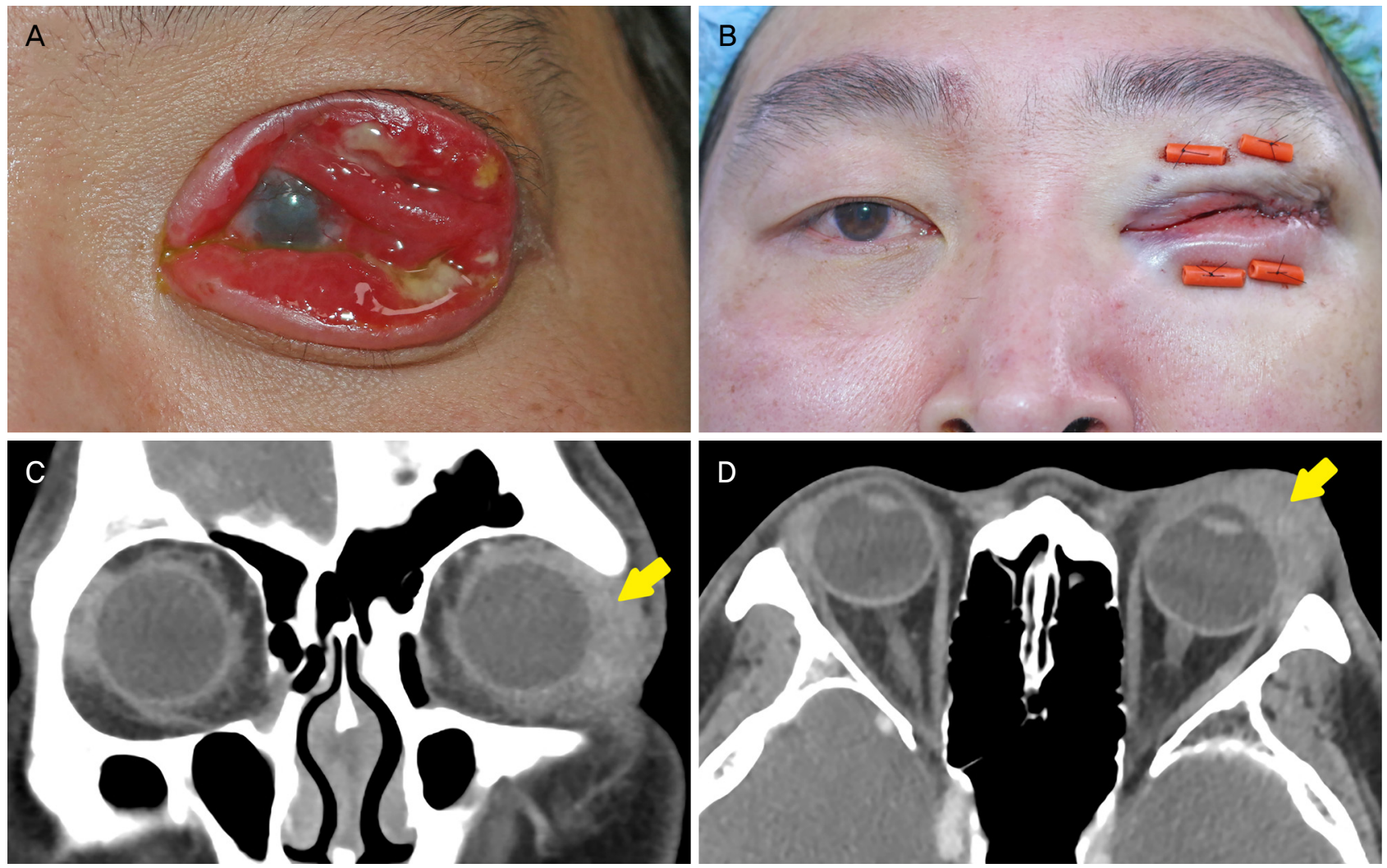

Figure 1. Photographs and orbital computed tomography. (A) Preoperative photo shows severe upper and lower tarsal ectropion with thickened upper eyelid, chronic conjunctival inflammation with prolapsed upper fornix. (B) Postoperative photo shows successfully corrected tarsal ectropion after excision of mass, modified spindle procedure and lateral tarsal strip. Orbital computed tomography in coronal view (C) and axial view (D) shows poorly-defined anterior orbital mass with enhancement involving the lacrimal gland and upper, lower eyelid of left eye (yellow arrows). The patient consented to the use of these photographs. 
되었지만 환자가 눈을 감거나 검사자가 눈꺼풀을 수평 방 향으로 당겨 팽팽하게 했을 때에도 위아래눈꺼풀판겉말림 은 호전되지 않았고, 특히 위눈꺼풀의 경우 검사자가 직접 위 눈꺼풀테를 아래쪽으로 당겼음에도 불구하고 제 위치로 돌 아가지 않았다. 안와 전산화단층촬영에서 좌안 안와 앞쪽에 서 상이측부터 하이측까지 이어지는 경계가 불분명한 연부 조직의 비후 및 눈물샘의 비대 소견을 보였다(Fig. $1 \mathrm{C}, \mathrm{D})$.

중증 위아래눈꺼풀판겉말림을 교정하기 위하여 국소마 취하에 변형된 방추형결막절제술(spindle procedure) 및 위 아래 가쪽눈꺼풀판띠교정술을 시행하였다. 여분의 위아래 눈꺼풀 결막을 내안각에서 외안각까지 수평으로 잘라낸 뒤 위눈꺼풀은 뮬러근, 아래눈꺼풀은 아래눈꺼풀당김기 일부 를 잘라냈다. 이후 안쪽방추형결막절제술(medial spindle operation)와 유사하게 Double-armed 5-0 ethilone 봉합사를 이용하여 위눈꺼풀은 뮬러근, 잘라낸 위눈꺼풀결막의 아래 쪽 가장자리를 순서대로 봉합하고 위결막구석에서 위눈꺼 풀 전층을 통과하여 안와위가장자리 부위의 피부쪽으로 나 오게 하였고, 아래눈꺼풀은 아래눈꺼풀당김기, 잘라낸 아래 눈꺼풀결막의 위쪽 가장자리를 순서대로 봉합하고 아래결 막구석에서 아래눈꺼풀 전층을 통과하여 안와아래가장자 리 부위의 피부쪽으로 나오게 하였다. 이와 같은 내회전 봉 합은 아래위아래눈꺼풀에 각각 두 군데씩 시행하였다(Fig. 1B). 수술 중 위눈꺼풀판 가측 부위에 단단하고 경계가 불분명 한 섬유화 조직 및 종괴가 관찰되어 주변 정상 조직을 보존 하면서 섬유화 조직 및 종괴를 최대한 절제한 후 조직검사 를 시행하였으며, 그 결과 림프형질세포의 침윤과 함께 면
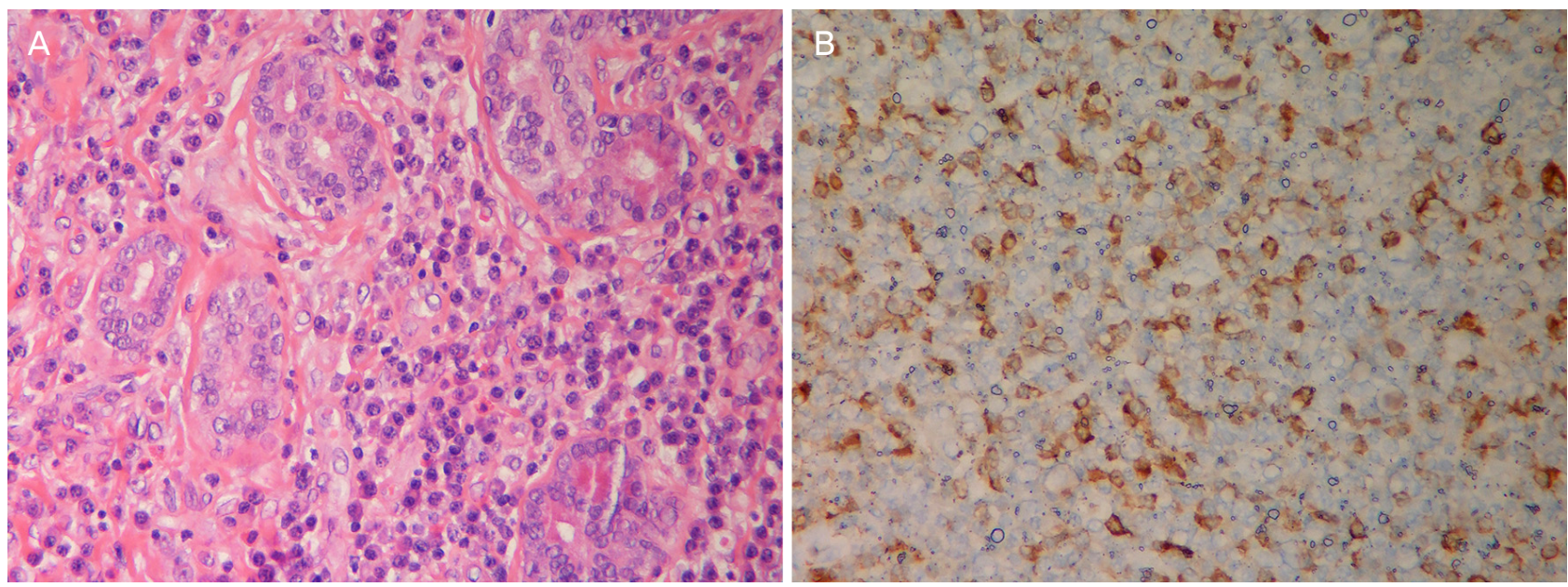

Figure 2. Histopathologic examination. (A) Histopathology of orbital mass shows extensive infiltration of lymphocytes and plasma cells with a few eosinophils in lacrimal gland (hematoxylin and eosin stain, $\times 400$ ). (B) The number of immunoglobulin G4 (IgG4)-positive plasma cells was above 50 per a high-power field $(\operatorname{IgG} 4, \times 400)$.
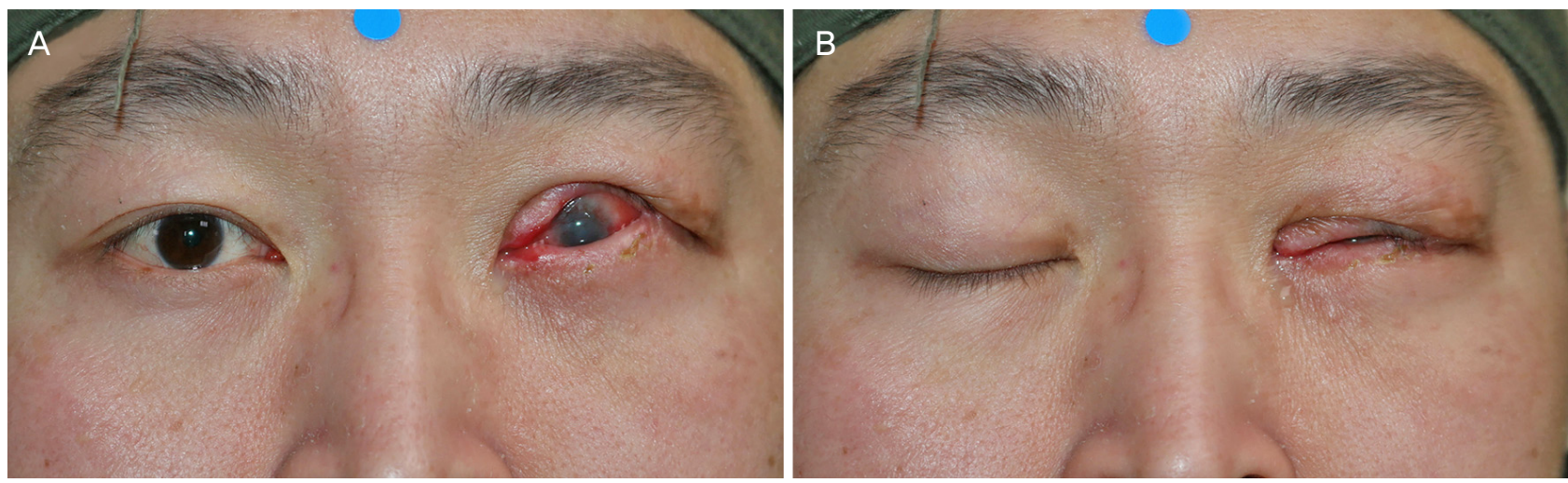

Figure 3. At one year after the surgery. (A, B) Postoperative photos of patient show the improvement of upper and lower tarsal ectropion. But mild lagophthalmos and upper lid retraction still remain. The patient consented to the use of these photographs. 
역화학염색에서 $\operatorname{IgG} 4 / \mathrm{IgG}$ 양성 형질세포 비율이 약 $62 \%$, 400 배율 현미경관찰시 $\mathrm{IgG} 4$ 양성 형질세포가 60 개가량 관찰 되었다(Fig. 2). 또한, 혈액검사에서 혈중 $\mathrm{IgG} 4$ 가 $202.5 \mathrm{mg} / \mathrm{dL}$, $\mathrm{IgE}$ 가 $158.0 \mathrm{mg} / \mathrm{dL}$ 로 상승되어 있어 면역글로불린G4관련 안질환으로 진단할 수 있었다. 이런 결과를 바탕으로 약 7년 전 당시 조직검사를 다시 확인해 본 결과 섬유화를 동반한 림프형질세포의 침윤 소견을 보여 당시에도 면역글로불린 $\mathrm{G} 4$ 관련안질환이 있었던 것으로 판단되었다. 기타 전신검사 및 영상의학검사에서 다른 장기의 침범은 확인되지 않았지 만, 수술 후 재발 방지를 위한 예방적 목적으로 경구스테로 이드제제 $10 \mathrm{mg}$ 을 3 주간 복용하였고, 이후 감량하여 $5 \mathrm{mg}$ 을 3 주간 추가로 복용하였다. 위아래눈꺼풀겉말림은 교정 되었으나 경미한 수준의 위눈꺼풀후퇴 및 토안은 남아있는 상태로(Fig. 3) 수술 후 1년이 지난 현재까지 증상의 재발 소견은 없었다.

\section{고 찰}

면역글로불린G4관련질환(IgG4-related disease)은 림프구 와 $\mathrm{IgG} 4$ 분비 형질세포의 조직침윤과 더불어 다양한 정도의 섬유화를 보이는 만성염증질환으로서 전신의 여러 장기를 침범하여 조직의 비후나 종괴의 형태로 나타난다. 전신적 으로 췌장, 담도, 후복막, 침샘, 안와, 림프절, 신장, 폐, 뇌 수막, 대동맥, 유방, 전립선, 갑상선 등에 흔히 발생하며, 다 른 장기의 침범 없이 안와에만 국한된 경우를 면역글로불 린G4관련안질환(IgG4-related ophthalmic disease)이라고 한 다. 한다. ${ }^{4}$ 눈물샘을 가장 흔하게 침범하고 그 외 삼차신경 이나 외안근, 눈꺼풀, 비루관을 침범하기도 하며 드물게는 공막을 침범하기도 한다. ${ }^{6}$ 면역글로불린G4관련안질환은 양 안에서 발생하는 경우가 많고, 일반적으로 평균 55.5 세에 발병하며 성별에 따른 차이는 없는 것으로 알려져 있다. ${ }^{7}$ 본 증례에서도 전신적인 침범 없이 좌안 눈물샘과 함께 가 쪽위눈꺼풀을 침범하는 면역글로불린G4관련안질환을 확인 할 수 있었지만, 일반적인 경우보다 조금 더 어린 30 대 초 에, 그리고 단안에 발생했다는 차이점이 있다.

면역글로불린G4관련안질환을 진단하기 위해 Goto et $\mathrm{al}^{5}$ 이 제시한 세 가지 기준에 따르면 눈물샘, 삼차신경, 외안 근을 포함한 다양한 안와 조직을 침범하는 것이 첫 번째 진 단 기준이다. 두 번째로는 병리조직학검사에서 저명한 림 프구와 형질세포의 침윤이나 섬유화를 보이고 종자 중심 (germinal center)을 관찰할 수 있으며, 면역세포학검사에서 $\mathrm{IgG} 4+/ \mathrm{IgG}+$ 형질세포의 비율이 $40 \%$ 이상 또는 400 배율 현 미경관찰시 $\mathrm{IgG} 4+$ 세포가 50 개 이상 관찰되는 것이다. 세 번째로는 혈액검사에서 혈청 $\mathrm{IgG} 4$ 수치가 $135 \mathrm{mg} / \mathrm{dL}$ 이상
인 것이다. 위에서 나열한 진단 기준에서 한 개만 만족할 때 possible, 두 개를 만족할 때 probable, 세 가지 모두 만 족할 경우 definite로 분류하게 된다. 본 증례 환자의 경우 좌안 눈물샘과 함께 가쪽위눈꺼풀을 침범하는 소견을 보였 고, $\mathrm{IgG} 4+/ \mathrm{IgG}+$ 형질세포 비율이 약 $62 \%, \mathrm{IgG} 4+$ 세포가 50 개 이상 관찰되었으며, 혈청 $\mathrm{IgG} 4$ 수치가 $202.5 \mathrm{mg} / \mathrm{dL}$ 로 확인되어 세 가지 진단 기준을 모두 만족하여 명확한(definite) 면역글로불린G4관련안질환으로 진단하였다.

눈꺼풀겉말림은 대부분 아래눈꺼풀에 발생하지만 드물 게 위눈꺼풀에 발생하기도 한다. 소아의 경우 출산 직후 결 막부종과 함께 수주간 일시적으로 위눈꺼풀겉말림이 발생 할 수 있고, ${ }^{8}$ 다운증후군이나 층판비늘증과 같은 유전질환 을 가진 경우에도 위눈꺼풀겉말림이 발생할 수 있다. ${ }^{9}$ 성인 의 위눈꺼풀겉말림은 반흔성 원인에 의해 발생하는 경우가 많으며, 눈둘레근의 만성적인 연축에 의한 경우도 있고, ${ }^{10}$ 국내에서는 극히 드물지만 국외에서는 헐거운눈꺼풀증후 군(floppy eyelid syndrome)에 의해 발생하는 경우도 많 다. ${ }^{3,11}$ 헐거운눈꺼풀증후군은 비만인 남성에서 심한 코골이 와 폐쇄수면무호흡증이 동반된 경우 발생하기 쉽다. 수면 중에 눈꺼풀이 뒤집어져 결막에 반복적인 자극 및 염증이 유발되고, 그 결과 유두결막염, 눈꺼풀판의 탄력섬유 소실 및 이완, 위눈꺼풀겉말림 등이 발생한다고 알려져 있다. ${ }^{11}$ 일반적으로 위눈꺼풀겉말림은 수면 중에만 발생하고 손으 로 쉽게 정위치시킬 수 있지만, 오랜 기간 지속될 경우 본 증례와 같이 심한 결막원개부종과 염증으로 인하여 제자리 로 되돌리기 힘든 경우도 보고된 바 있다. ${ }^{12}$ 몇몇 연구에서 면역글로불린G4관련안질환과 관련된 눈꺼풀겉말림을 보고 한 바 있으나 본 증례와는 달리 눈꺼풀판의 비후와 관련된 기계적 아래눈꺼풀겉말림이었다. ${ }^{13,14}$ 본 증례와 같이 눈꺼 풀판 전체가 뒤집어지는 심한 위아래눈꺼풀판겉말림이 발 생한 이유는 첫째, 헐거운눈꺼풀증후군과 유사하게 만성적 으로 반복되는 면역글로불린G4관련염증이 가쪽눈구석인대 및 눈꺼풀판의 이완을 유발하였고, 둘째, 눈꺼풀의 비후 및 종괴에 의한 기계적 원인, 그리고 마지막으로 만성 염증으 로 인한 반흔성 수축에 의한 것으로 생각되며, 특히 이런 복합적인 원인들에 의해 헐거운눈꺼풀증후군과는 달리 위 눈꺼풀겉말림을 손으로 정위치시킬 수 없는 특징을 보였다.

퇴행눈꺼풀겉말림의 중요한 발생 원인은 눈꺼풀의 수평 이완과 아래눈꺼풀당김기의 이완 및 해리이며, 이를 교정 하기 위해 여러 수술 방법들이 고안되어 왔다. 아래눈꺼풀 의 수평이완을 단축시키기 위해서 가장 흔히 사용되는 방 법이 가쪽눈꺼풀판띠고정술이며, 그 외에 오각형모양절제 술, lazy-T 수술법, 외안각고정술(canthopexy) 등이 사용된 다. 위눈꺼풀겉말림, 특히 헐거운눈꺼풀증후군에서는 눈꺼 
풀판 오각형모양절제술, 가쪽눈꺼풀판띠고정술, 내안각 및 외안각고정술 또는 겹치기, 귓바퀴연골 이식술 등과 같은 다양한 방법을 사용한다. ${ }^{11}$ 하지만 본 증례와 같이 눈꺼풀 판 전체가 뒤집어진 심한 눈꺼풀판겉말림(tarsal ectropion) 에서는 눈꺼풀수평이완과 함께 아래눈꺼풀당김기, 눈꺼풀 올림근막 및 뮬러근의 이완 및 완전한 해리가 동반되기 때 문에 수평이완만을 단축시킬 경우 눈꺼풀겉말림의 교정 효 과가 부족하거나 재발할 가능성이 높다. 그래서 여러 연구 자들이 아래눈꺼풀당김기를 재부착시키고 눈꺼풀판의 회 전을 막기 위해 여러 가지 수술 방법들을 제시하였다. 특히 나 Ko and $\mathrm{Kim}^{1}$, Tse et $\mathrm{al}^{15}$ 은 심한 아래눈꺼풀겉말림 환 자에서 눈꺼풀 내측뿐만 아니라 외측까지 절제하는 변형된 방추형절제술을 이용하여 아래눈꺼풀당김김의 재부착뿐만 아니라 내회전봉합술을 통하여 더욱 안정적인 수술 결과를 도모하였다. 본 증례에서는 눈꺼풀겉말림의 근본 원인이라 고 할 수 있는 결막원개부종 및 면역글로불린G4관련안질 환에 의한 종괴를 최대한 절제하여 기계적 원인을 제거하 였고, 위아래눈꺼풀의 수평이완은 가쪽눈꺼풀판띠고정술로 교정하였으며, 이들만으로 부족한 부분은 위아래눈꺼풀에 변형된 방추형절제술을 시행하여 성공적으로 교정할 수 있 었다. 하지만, 염증에 의한 반흔성 수축으로 인해 수술 후 에도 경미한 위눈꺼풀 후퇴가 남아있음을 확인할 수 있었 다.

본 증례는 만성적으로 반복되는 면역글로불린G4관련염 증으로 인해 위아래눈꺼풀 전체가 뒤집히는 중증의 위아래 눈꺼풀판겉말림이 발생한 환자였다. 이런 경우 눈꺼풀의 수평이완만을 교정해서는 재발이나 부족 교정의 가능성이 높으므로 원인이 되는 종괴 제거와 함께 눈꺼풀의 전후 회 전을 막는 아래눈꺼풀당김기, 눈꺼풀올림근막 또는 뮬러근 의 재부착 및 내회전봉합술이 필요하겠다.

\section{REFERENCES}

1) Ko SJ, Kim SD. Involutional ectropion repair with the modified medial spindle and the lateral tarsal strip procedure. J Korean Ophthalmol Soc 2012;53:187-92.

2) Vallabhanath P, Carter SR. Ectropion and entropion. Curr Opin Ophthalmol 2000;11:345-51.

3) Netland PA, Sugrue SP, Albert DM, Shore JW. Histopathologic features of the floppy eyelid syndrome. Involvement of tarsal elastin. Ophthalmology 1994;101:174-81.

4) Umehara $H$, Okazaki K, Masaki Y, et al. Comprehensive diagnostic criteria for IgG4-related disease (IgG4-RD), 2011. Mod Rheumatol 2012;22:21-30.

5) Goto H, Takahira M, Azumi A, Japanese Study Group for IgG4Related Ophthalmic Disease. Diagnostic criteria for IgG4-related ophthalmic disease. Jpn J Ophthalmol 2015;59:1-7.

6) Wallace ZS, Deshpande V, Stone JH. Ophthalmic manifestations of IgG4-related disease: single-center experience and literature review. Semin Arthritis Rheum 2014;43:806-17.

7) McNab AA, McKelvie P. IgG4-related ophthalmic disease. Part I: background and pathology. Ophthalmic Plast Reconstr Surg 2015;31:83-8.

8) Kirkpatrick A, Ledlow D, Dixon E, Philips JB. Congenital bilateral eyelid eversion and chemosis: a case study. Neonatal Netw 2018; 37:137-40.

9) Watts MT, Dapling RB. Congenital eversion of the upper eyelid: a case report. Ophthalmic Plast Reconstr Surg 1995;11:293-5.

10) Koh S, Hosohata J, Tano Y. Bilateral upper eyelid ectropion associated with blepharospasm. Br J Ophthalmol 2006;90:1437-8.

11) Lee CC, Lai HT, Kuo YR, et al. Floppy eyelid syndrome: an unfamiliar entity for plastic surgeons. Ann Plast Surg 2018;80(2S Suppl 1):S40-7.

12) Leibovitch I, Davis G, Selva D, Hsuan J. Non-cicatricial upper eyelid ectropion. Br J Ophthalmol 2005;89:1226-7.

13) Nagai T, Yunoki T, Hayashi A. A case of IgG4-related bilateral palpebral conjunctivitis. Case Rep Ophthalmol 2019;10:299-303.

14) Silverman N, Lanjewar S, Gupta R, Shinder R. IgG4-Related disease of the punctum and canliculus. Ophthalmic Plast Reconstr Surg 2017;33:165-7.

15) Tse DT, Kronish JW, Buus D. Surgical correction of lower-eyelid tarsal ectropion by reinsertion of the retractors. Arch Ophthalmol 1991;109:427-31. 


\section{= 국문초록 $=$}

\section{면역글로불린G4관련안질환을 동반한 중증 위아래눈꺼풀판겉말림}

목적: 위눈꺼풀겉말림은 극히 드문 질환으로 면역글로불린G4관련안질환에 의한 중증 위아래눈꺼풀판겉말림을 진단하고 성공적인 치 료를 경험하였기에 이를 보고하고자 한다.

증례요약: 37 세 남자 환자가 7 여년 전부터 반복되는 좌안 눈꺼풀주위 부종 및 염증을 주소로 내원하였다. 중증의 좌안 위아래눈꺼풀판 겉말림, 위눈꺼풀 부종 및 종괴, 위눈꺼풀결막원개 탈출증 등의 소견을 보였고, 안와 전산화단층촬영에서 좌안 위아래눈꺼풀 연부조직 과 눈물샘의 비대가 관찰되었다. 위아래눈꺼풀판겉말림을 교정하기 위하여 변형된 방추형결막절제술(spindle procedure) 및 위아래 가쪽눈꺼풀판띠교정술을 시행하였다. 수술 중 위눈꺼풀판 가측 부위에 단단하고 경계가 불분명한 섬유화 조직 및 종괴가 관찰되어 종괴절제 및 조직검사를 시행하였다. 혈액 및 조직검사에서 면역글로불린G4관련안질환에 합당한 소견을 보여 면역글로불린G4관련안 질환에 의한 중증 위아래눈꺼풀판겉말림으로 진단할 수 있었다.

결론: 본 증례와 같이 만성염증에 의한 중증 위아래눈꺼풀판겉말림이 발생한 경우 원인이 되는 종괴 제거와 함께 눈꺼풀수평이완의 단축 및 눈꺼풀의 전후 회전을 막는 변형된 방추형결막절제술이 필요하겠다.

〈대한안과학회지 2020;61(8):944-949〉

오준호 / Jun Ho Oh

경북대학교 의과대학 안과학교실

Department of Ophthalmology,

School of Medicine,

Kyungpook National University

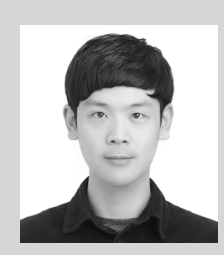

